\title{
SISTEM PENDUKUNG KEPUTUSAN PEMILIHAN DOSEN BERPRESTASI DI UNIVERSITAS KHAIRUN TERNATE DENGAN METODE MULTI- ATTRIBUTE UTILITY THEORY
}

\author{
Ani Adam ${ }^{1}$, Achmad Fuad², Hairil K Sirajuddin ${ }^{3}$, Syarifuddin N Kapita ${ }^{4}$ \\ ${ }^{1,2,3}$ Program Studi Teknik Informatika, Fakultas Teknik, Universitas Khairun \\ Jl. Jati Metro, Kota Ternate Selatan \\ Email : anhyadam6@gmail.com ${ }^{1}$, fuad@unkhair.ac.id ${ }^{2}$, hairil.kurniadi@unkhair.ac.id ${ }^{3}$, \\ syarif.kapita@unkhair.ac.id ${ }^{4}$
}

(Naskah masuk: 3 Oktober 2020, diterima untuk diterbitkan: 10 November 2020)

\begin{abstract}
Abstrak
Pemilihan dosen berprestasi di Universitas Khairun yang digunakan selama ini masih bersifat konvensinal, dimulai dari penyampaian informasi sampai pada tahap pemberian nilai. Untuk itu, perlu diterapkan sebuah metode pendukung keputusan sebagai solusi yang ditawarkan dalam pemilihan dosen berprestasi. Penelitian ini bertujuan untuk mengembangkan sistem reomendasi pemilihan dosen berprestasi di Universitas Khairun Ternate. Sistem ini menggunakan metode Multi-Attributte Utillity Theory (MAUT), MAUT digunakan untuk merubah dari beberapa kepentingan ke dalam nilai numerik dengan skala $0-1$, 0 mewakili pilihan terburuk dan 1 terbaik. Hasil pengujian sistem didapatkan nilai tertinggi hingga nilai terendah. Pada hasil perangkingan terdapat nilai tertinggi yaitu dengan nilai=300 dan nilai terendah dengan nilai=40. Hasil akhir yang diharapkan adalah mendapatkan sejumlah rekomendasi dosen dengan nilai tertinggi hingga nilai terendah. Dengan dibuat SPK pemilihan dosen berprestasi diharapkan mampu mempermudah dalam pemilihan dosen berprestasi. Hasil pengujian sistem dengan menggunakan metode pengujian sistem white box telah berhasil dilakukan. Dimana dengan melakukan pengujian pada setiap path-path dalam 13 kali pengujian, Pengujian menunjukkan bahwa sistem informasi ini berjalan sesuai dengan yang diharapkan, dan tidak terjadi kesalahan logika.
\end{abstract}

Kata kunci: SPK, MAUT, pemilihan dosen berprestasi.

\section{DECISSION SUPPORT SYSTEM FOR SELECTING LECTURER ACHIEVEMENT AT KHAIRUN TERNATE UNIVERSITY USING MULTI-ATTRIBUTE UTILITY THEORY METHOD (MAUT)}

\begin{abstract}
The selection of outstanding lecturers at Khairun University used so far is still conventional, starting from the delivery of information to the grading stage. For this reason, it is necessary to apply a decision support method as a solution offered in selecting outstanding lecturers. This study aims to develop a recommendation system for selecting outstanding lecturers at Khairun Ternate University. This system uses the Multi-Attributte Utility Theory (MAUT) method, MAUT is used to convert from several interests into numerical values with a scale of 0-1, 0 representing the worst choice and 1 being the best. The system test results obtained the highest value to the lowest value. In the ranking results, there is the highest value with a value $=300$ and the lowest value with a value $=40$. The expected final result is to get a number of lecturer recommendations with the highest score to the lowest score. By making the SPK selection of outstanding lecturers, it is hoped that it will be able to facilitate the selection of outstanding lecturers. The results of system testing using the white box system testing method have been successfully carried out. Where by testing each path in 13 tests, the test shows that this information system is running as expected, and there are no logical errors.
\end{abstract}

Keywords: DSS, MAUT, lecturer achievement selection. 


\section{Pendahuluan}

Tugas dari seorang Dosen adalah dengan menjalankan Tri Dharma Perguruan Tinggi, yaitu melaksanakan pendidikan, melakukan riset dan development, terhapdap IPTEK, serta melakukan Kegiatan Pengabdian kepada Masyarakat (PKM). Dengan kompleksitas kegiatan tersebut, maka perlu diberikan semacam reward, dalam rangka peningkatan kualitas dan perbaikan serta kemajuan ilmu pengetahuan, Reward diberikan sebagai motivasi untuk mendorong kepada para dosen agar lebih produktif dan berinovasi dalam pengembangan pembelajaran di Perguruan Tinggi,

Universitas Khairun Ternate adalah salah satu perguruan tinggi negeri yang terdapat di Kota Ternate, Maluku Utara, Indonesia. Universitas Khairun terdapat 8 fakultas dan 32 program studi dengan jumlah dosen tetap sebanyak 582 orang. Universitas Khairun sering mengadakan kegiatan pemilihan dosen berprestasi setiap tahunnya secara rutin dan dilakukan sampai sekarang. Pemilihan dosen berprestasi dilakukan oleh tim penilai yang telah dibentuk. Adapun cara yang digunakan selama ini masih bersifat konvensinal dengan membagikan formulir ke setiap program studi, nantinya program studi bersangkutan yang merekomendasikan dosen-dosennya untuk ditindaklanjuti di tingkat fakultas. Cara ini tentunya prosesnya lama dan kurang efektif sehingga perlu dilakukan penerapan suatu sistem yang dapat membantu panitia dalam memilih dosen berprestasi.

Salah satu caranya yaitu dengan membangun sistem pendukung keputusan. Sistem pendukung keputusan untuk pemilihan dosen berprestasi telah dilakukan oleh beberapa peneliti sebelumnya yaitu [1] membangun SPK pemilihan dosen berprestasi di STIMIK Tasikmalaya. Metode yang digunakan yaitu metode SAW. Kemudian [2] menerapkan SPK pemilihan dosen berprestasi menggunakan metode TOPSIS dan ANP. Sedangkan pada penelitian menggunakan metode Multi-Atributte Utillity Theory pada data dosen yang ada di universitas khairun ternate. [3] membangun SPK memilih dosen terbaik di Adisutjipto Institute of Technology dengan menggunakan metode collaborative filtering. [4] membangun SPK untuk memilih guru terbaik Bahasa inggris dengan menggunakan metode SMART dan TOPSIS.

Beberapa penelitian telah menerapkan metode MAUT untuk proses pendukung keputusan. Sebagaimana yang dilakukan oleh [5] yaitu untuk pemilihan tenaga Kesehatan teladan di kota Ternate. Hasil penelitian menunjukkan bahwa metode MAUT dapat membantuk panitia dalam memilih tenaga Kesehatan teladan di dinas Kesehatan kota Ternate. Kemudian [6] membangun sistem pendukung keputusan pada rekomendasi web hosting. Dan hasil penerapan metode MAUT dapat membantu user dalam pemilihan web hosting yang sesuai dengan kriterianya.
Pembuatan Sistem Pendukung Keputusan (SPK) ini diharapkan akan menyelesaikan permasalahan yang dihadapi, dan menghasilkan rekomendasi keputusan yang bisa membantu tim Penilai untuk menentukan siapa yang benar-benar layak mendapat predikat dosen berprestasi.

\section{METODE PENELITIAN}

\subsection{Sistem Pendukung Keputusan}

SPK adalah suatu model pendekatan (metodologi) untuk membantu pimpinan pengambilan keputusan. DSS (Decision Support System), menggunakan CIBIS yang fleksibel, interaktif, dan dapat diadaptasi, yang dikembangkan untuk untuk memberikan solusi dalam penyelesaian masalah secara spesifik terhadap manajemen yang belum tersusun atau terstruktur dengan baik. DSS (Decision Support System) menyediakan data, tampilan yang user friendly, serta bisa bisa mengkombinasikan dan menggabungkan ada yang dipikirkan oleh pengambil keputusan [7].

Sebagai tambahan, DSS (Decision Support System) biasanya menggunakan berbagai model dan dibangun (sering oleh pengguna akhir) oleh suatu proses interaktif dan iteratif. la mendukung semua fase pengambilan keputusan dan dapat memasukkan suatu komponen pengetahuan. DSS (Decision Support System) dapat digunakan oleh pengguna tunggal pada satu PC atau bisa menjadi berbasisWeb untuk digunakan oleh banyak orang pada beberapa lokasi [5].

\subsection{Multi-Attribute Utility Theory (MAUT)}

Multi-Atribute Utility Theory (MAUT) adalah sebuah kerangka dalam analisi akhir, $\mathrm{v}(\mathrm{x})$ dari sebuah objek $\mathrm{x}$ diartikan sebagai bobot yang dijumlahkan dengan sebuah nilai yang bermakna untuk nilai dimensinya. Istilah ini sering disebutkan dengan nama nilai utilitas. MAUT digunakan untuk mengganti sejumlah kepentingan kedalam nilai numerik dengan skala 0-1 dimana 0 adalah pilihan terburuk dan 1 terbaik. Sehinnga mendapat kemngkinan terjadinya perbandingan langsung yang dengan bermaca-macam ukuran. Akhir dari proses in adalah mendapatkan rangking/urutan dari hasil evaluasi yang dilakukan oleh pembuat keputusan. Keseluruhan dari nilai evaluasi bisa digambarkan dengan persamaan: Normalisasi matrik menggunakan Persamaan 1 [6]:

$U_{(x)}=\frac{x-x i^{-}}{x i^{+}-x i^{-}}$

Normalisasi Atribut menggunakan persamaan 2 [8]:

$$
V(x)=\sum_{i=1}^{n} W_{j} . X i j
$$

\subsection{Metode Pengembangan Sistem}

Untuk proses pengembangan sistem ini menggunakan Model Waterfall. Model ini 
merupakan sebuah suatu bentuk proses untuk membentuk sebuah perangkat lunak yang dikembangkan secara terstruktur dan berurutan dimulai dari penentuan masalah Analisis sistem, Desain Pengkodean, ujicoba, dan Pemliharan system [9]. Berikut gambar 1 merupakan tahapan Metode Waterfall.

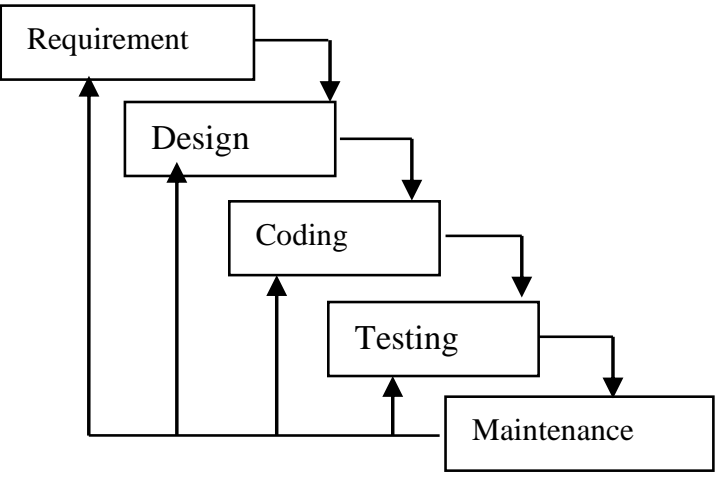

Gambar 1. Bagan Model Waterfall

1. Tahap Requeirement

Pada tahapan ini. Dilakukan proses menganalisis hal-hal yang dibutukan pembuatan system, diantaranya adalah dengan melakukan kegiatan pengumpulan data dengan cara melakukan interview dan mencari referensi (literature) yang saling berhubungan. Pada tahapan ini pengembang system harus mencari informasi dari para pengguna system, sehingga system yang dikembangkan nanti sesuai dengan keinginan dan kebutuhan pengguna.

2. Tahap Design

Tahapan design adalah bagaimana menterjemahkan semua keperluan sistem ke dalam sebuah sistem yang akan dirancang, sebelum masuk e proses pengkodean. tahapan ini dititikberatkan pada inisialisasi struktur data, arsitektur perangkat lunak, tampilan, dan algoritma. Tahapan ini akan menghasilkan dokumen yang disebut software requirement. Dokumen inilah yang akan digunakan programmer untuk melakukan aktivitas sistemnya.

3. Tahap Pengkodean (Coding)

Tahapan ini adalah proses menerjemahkan dan mentransformasikan rancangan tampilan ke dalama bahasa pemrograman yang bisa dimengerti oleh computer. Pada tahapan ini merupakan bagian implementasi secara nyata dari sebuah sistem

\section{Tahap Testing}

Tahapan ini dilakukan setelah proses pengkodean selesai, dimana sebelum sistem digunakan, dilakukan ujicoba terlebih dahulu oleh user, untuk menghindari terjadinya error (bug) di daam perangkat lunak yang dikembangkan.

\section{Tahap Maintenance}

Tahap ini adalah poses pemeliharaan sistem, dengan cara melakukan update sistem untuk mengikuti perkembangan teknologi serta untuk kepentingan adaptasi terhadap model perangkat lunak yang terbarukan.

\section{Desain Use Case Diagram}

a. Use Case Diagram Admin/PTU)

Admin dalam menggunakan sistem ini nantinya memiliki hak akses tersendiri. Sebagaimana ditunjukkan pada Gambar 2.

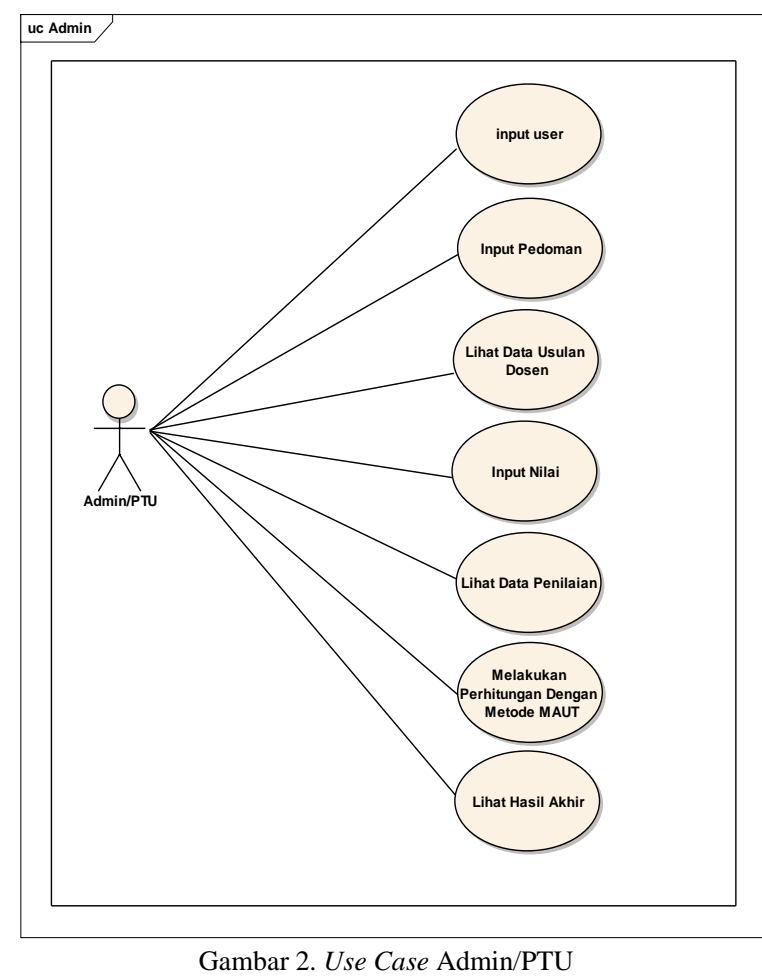

b. Use Case Diagram User

Selain admin yang memiliki hak akses tersendiri user juga memiliki hak akses. Sebagaimana desain ditunjukkan pada use case diagram user pada Gambar 3.

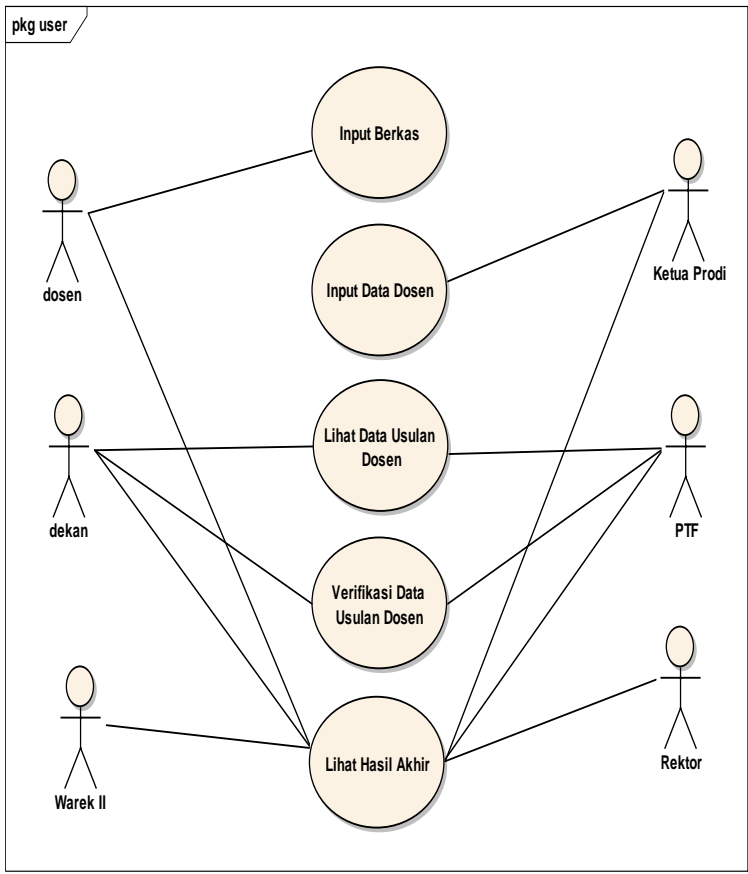

Gambar 3 Use Case User 
c. Implementasi Metode MAUT

Pada metode MAUT terdapat 2 tahapan penyelesaian perhitungan yaitu tahap pertama normalisasi matriks dan tahap kedua perkalian bobot. Kriteria yang dipakai dalam perhitungan metode MAUT ini ada 2 kriteria dan 7 sub kriteria. Pada perhitungan metode (MAUT) hasil akhir akan menghasilkan perangkingan. Adapun Langkahlangah ditunjukkan pada Gambar 4 dalam bentuk flowchart.

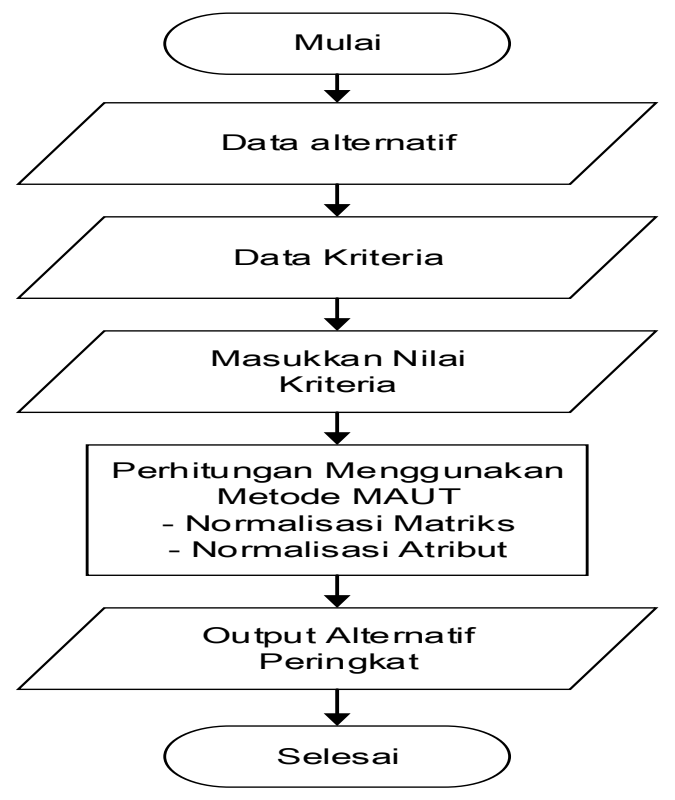

Gambar 4. Flowchart (MAUT)

Langkah-langkah metode Multi-Atributte Utility Theory (MAUT) yaitu dimulai dengan mulai, setelah itu pilih data alternatif, selanjutnya tentukan data kriteria, masukkan nilai kriteria yang telah ditentukan, selanjutnya melakukan perhitungan dan terakhir mendapatkan hasil rangking.

\subsection{Pengujian Sistem}

Sistem yang dibangun selain dilakukan pengujian data-data dosen berprestasi dengan metode MAUT sistem juga dilakukan pengujian perangkat lunak dengan menggunakan white box testing. Perngujian white box untuk untuk membuat pengukuran kompleksitas logikal dari rancangan prosedural dan menggunakan pengukuran ini sebagai panduan untuk mendefinisikan himpunan basis dari jalur eksekusi [10].

\section{HASIL DAN PEMBAHASAN}

\subsection{Implementasi Sistem}

Pada tahapan ini dilakukan dengan pembuatan database, interfaces dan penulisan kode program. Adapun bahasa pemrograman yang digunakan adalah PHP. Tampilan Interface Sistem

1. Halaman Login
Pada halamanlogin ini digunakan untuk masuk ke dalam sistem, modul ini berlaku untuk semua level user baik PTU (Panitia Tingkat Universitas),PTF (Panitia Tingkat Fakultas, Dekan,Ketua Prodi, Dosen,Rektor dan Wakil Rektor II. Adapun Tampilan login dapat dilihat pada gambar 5.

\section{Sistem Pendukung Keputusan (SPK) Pemilihan Dosen Berprestasi Menggunakan Metode Maut}

SPK Maut in thone il agin

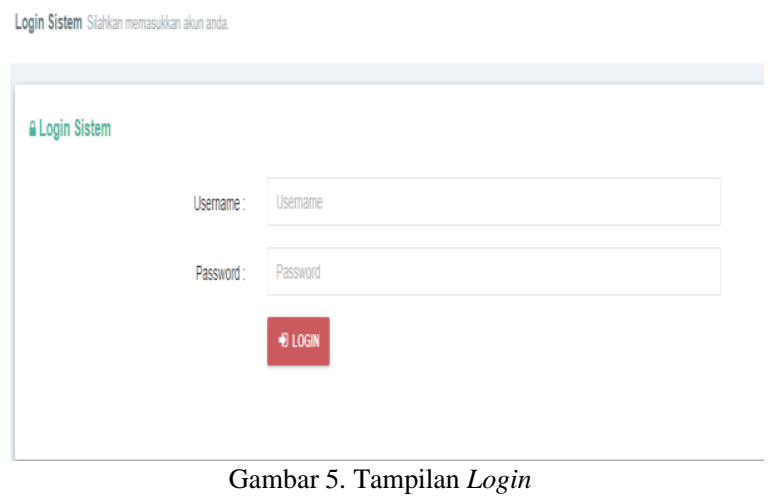

Pada gambar 5 yaitu dari halaman login, terdapat beberapa item yaitu: username, password serta tombol login. Pada tampilan tersebut digunakan untuk semua level user yaitu PTU (Panitia Tingkat Universitas),PTF (Panitia Tingkat Fakultas, Dekan,Ketua Prodi, Dosen,Rektor dan Wakil Rektor II

\section{Halaman PTF}

Pada halaman utama PTF terdapat 2 menu utama yaitu: Data dosen, Verifikasi dosen. Adapun tampilan menuutama PTF dapat dilihat pada gambar 4.3 dan flowchart menu utama PTF dapat dilihat pada gambar 6 .

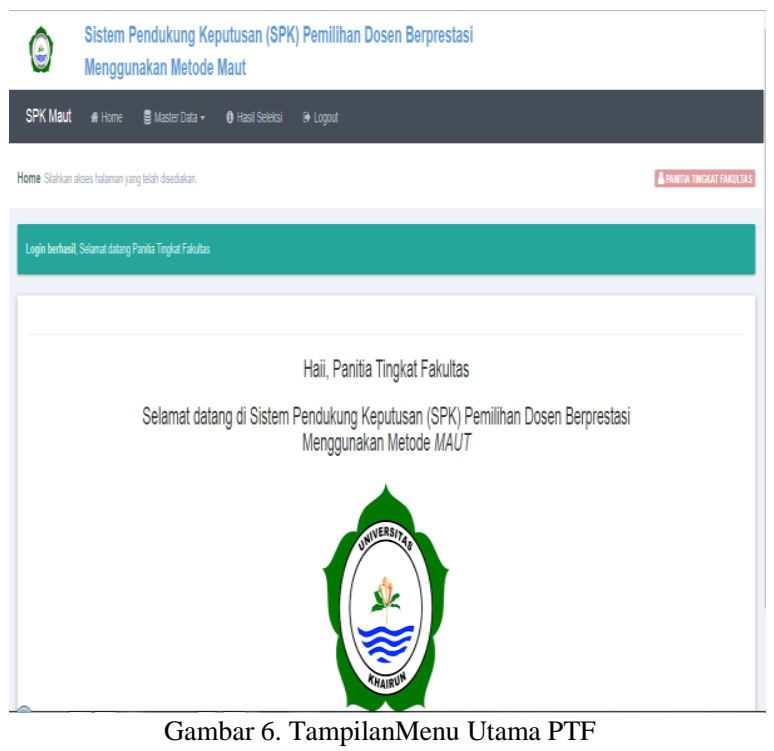


Pada gambar 6 adalah tampilan halaman utama PTF, pada halaman ini terdapat 3 modul utama yaitu: modul master data, modul hasil seleksi, dan logout. Dalam modul master data terdapat 2 item yaitu: data usulan dosen berprestasi dan verifikasi usulan dosen berprestasi. Sebagaimana ditunjukkan pada pada Gambar 7.

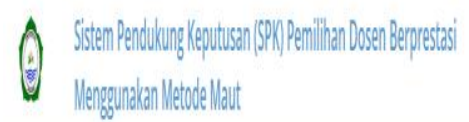

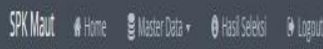

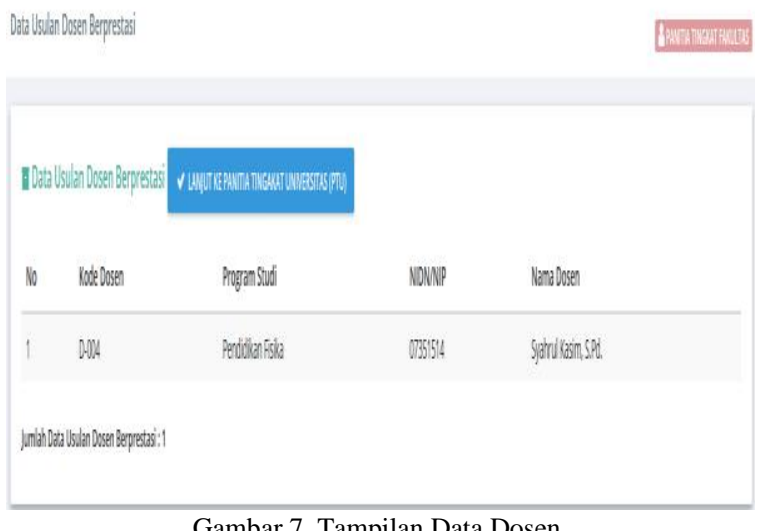

Gambar 7. Tampilan Data Dosen

Pada gambar 8 adalah rekomendasi dosen berprestasi dari masing-masing dekan. Dalam tampilan data dosen terdapat beberapa item yaitu: kode dosen, program studi, NIDN/NIP, dan nama dosen, dan tombol "lanjut ke panitia tingkat universitas (PTU)".

A Sistem Pendukung Keputusan (SPK) Pemilihan Dosen Berprestasi

Mengegunakan Metode Maut

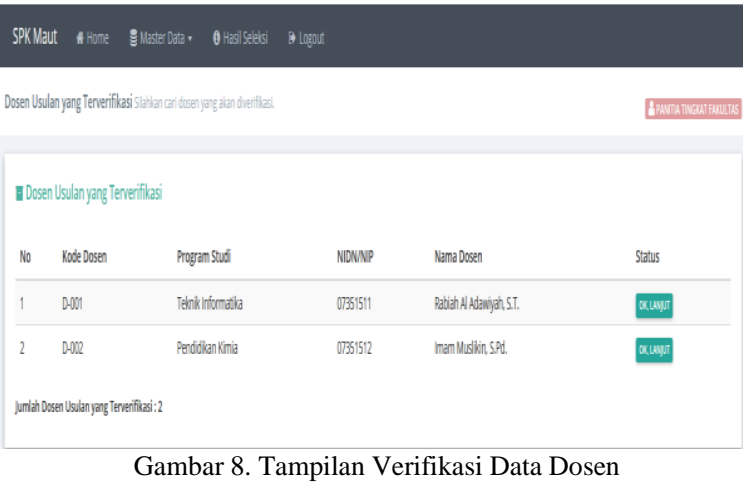

Verifikasi data dosen pada gambar 8 adalah rekomendasi dosen berprestasi tingkat fakulas yang telah di verifikasi dan akan dikirim ke panitia tingkat universitas. Pada tampilan verifikasi data dosen terdapat beberapa item yaitu: tombol lakukan pencarian, kode dosen, program studi, NIDN/NIP, nama dosen.

\subsection{Perhitungan Metode MAUT}

Pada menu ini master data dapat melakukan perhitungan proses SPK setelah data-data dosen di terima dari masing-masing fakultas, yaitu terdapat proses perhitungan matriks normalisasi, perkalian matriks atribut, pembobotan hasil perkalian matriks,serta perangkingan usulan dosen berprestasi di Universitas Khairun. Pada Script perhitungan normalisasi matriks nilai dosen yang dimaksudkan adalah nilai alternatif. Adapun tampilan daftar usulan dosen berprestasi yang telah di nilai dapat dilihat pada gambar 9, tampilan hasil perangkingan dapat dilihat pada gambar 10 .

\section{A Sistem Pendukung Keputusan (SPK) Pemilihan Dosen Berprestasi Menggunakan Metode Maut}

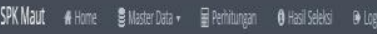

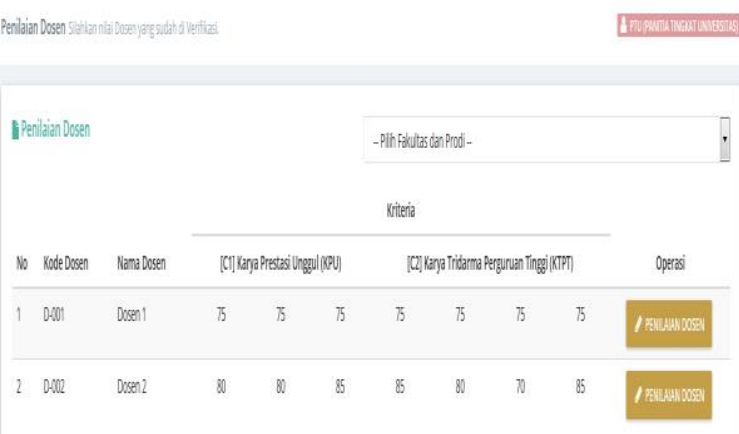

Gambar 9. Tampilan Rating Kecocokan MAUT

Pada tampilan gambar 9 adalah daftar nilai dosen yang akan di proses untuk penentuan perhitungan SPK, yaitu perhitungan matriks normalisasi berdasarkan kriteria yaitu kriteria K1 sampai dengan $\mathrm{k} 2$. Berikut adalah tabel hasil rating kecocokan:.

Tabel 4.1 Rating Kecocokan MAUT

\begin{tabular}{cccc}
\hline & \multicolumn{2}{c}{ Alternatif } \\
& No & Dosen 1 & Dosen 2 \\
\hline \multirow{3}{*}{ K1 } & 1 & 75 & 80 \\
& 2 & 75 & 80 \\
& 3 & 75 & 85 \\
& 1 & 75 & 85 \\
& 2 & 75 & 80 \\
$\mathrm{~K} 2$ & 3 & 75 & 70 \\
& 4 & 75 & 85 \\
\cline { 2 - 3 } & & &
\end{tabular}

Normalisasi matriks menggunakan persamaan 1 Alternatif 1
A $1 \mathrm{~K} 11=\frac{75-75}{\mathrm{80}-75}=0$
$\mathrm{K} 21=\frac{75-75}{85-75}=0$
A1 K12 $=\frac{75-75}{80-75}=0$
$\mathrm{K} 22=\frac{75-75}{80-75}=0$ 


$$
\begin{aligned}
& \mathrm{A} 1 \mathrm{~K} 13=\frac{75-75}{85-75}=0 \\
& \mathrm{~K} 23=\frac{75-70}{75-70}=1 \\
& \mathrm{~K} 24=\frac{75-75}{85-75}=0
\end{aligned}
$$

Alternatif 2

$$
\begin{aligned}
& \mathrm{A} 1 \mathrm{~K} 11=\frac{\mathrm{80}-75}{\mathrm{80}-75}=1 \\
& \mathrm{~K} 21=\frac{\mathrm{85}-75}{85-75}=1 \\
& \mathrm{~A} 1 \mathrm{~K} 12=\frac{\mathrm{g0}-75}{\mathrm{80}-75}=1 \\
& \mathrm{~K} 22=\frac{\mathrm{80}-75}{\mathrm{80}-75}=1 \\
& \mathrm{~A} 1 \mathrm{~K} 13=\frac{\mathrm{85}-75}{\mathrm{85}-75}=1 \\
& \mathrm{~K} 23=\frac{\mathrm{80}-75}{\mathrm{80}-75}=1 \\
& \mathrm{~K} 24=\frac{\mathrm{85}-75}{85-75}=1
\end{aligned}
$$

Normalisasi Atribut menggunakan persamaan 2.

$$
\begin{aligned}
& \mathrm{A} 1=(0 \times 60)+(0 \times 60)+(0 \times 60)+(0 \times 40)+(0 \times \\
& 40)+(1 \times 40)+(0 \times 40) \\
& =40 \\
& \mathrm{~A} 2=(1 \times 60)+(1 \times 60)+(1 \times 60)+(1 \times 40)+(1 \\
& \mathrm{x} 40)+(1 \times 40)+(1 \times 40) \\
& =300
\end{aligned}
$$

\section{A Sistem Pendukung Keputusan (SPRK) Pemilihan Dosen Berperstasi Mengevanakan Netode Maut}
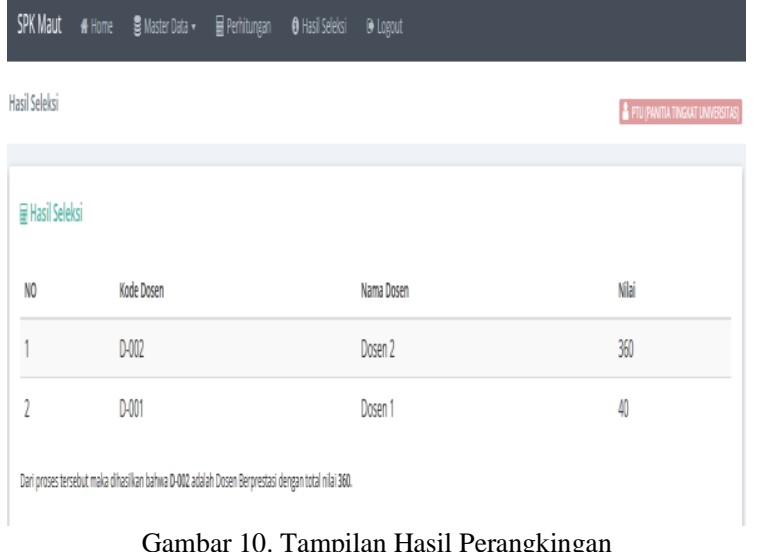

Pada tampilan gambar 10 adalah tahapan akhir dari perangkingan. Kesimpulan dari proses perangkingan adalah, pada A1 $=40$ A2 $=300$, maka rekomendasi yang diperoleh dengan nilai tertinggi dan terbesar ada pada A2, sehingga alternatif A2 adalah alternatif yang terpilih sebagai pemenang pemilihan dosen berprestasi di Unkhair.

\subsection{Pengujian Sistem}

Untuk melakukan pengujian sistem dengan white box pertama adalah dibuat flowgraph sebagaimana ditunjukkan pada Gambar 11.

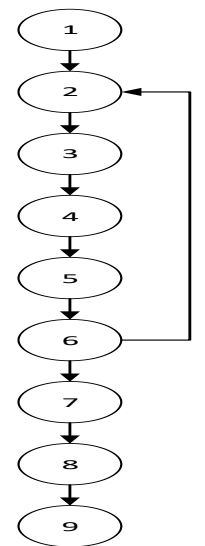

Gambar 11. Flowgraph Modul Perhitungan

Keterangan:

- $\quad$ Node $(\mathrm{N}): 9$

- Edge : 9

- $\quad$ Predikat $(\mathrm{P}): 1$

- Cylomatic Complexcity

$$
\begin{aligned}
\circ \mathrm{V}(\mathrm{G})= & (\mathrm{E}-\mathrm{N})+2 \\
& =(9-9)+2 \\
& =0+2 \\
& =2 \\
\circ \mathrm{V}(\mathrm{G})= & \mathrm{P}+1 \\
& =1+1 \\
& =2
\end{aligned}
$$

- Indenpendent path:

Path 1:123456789

Path $2: 12345623456789$

Berdasarkan pada hasil yang didapatkan Cylomatic Complexcity, dan Indenpendent Path bernilai 2, maka kesimpulannya bahwa modul perhitungan dapat dikatakan valid.

Metode pengujian sistem yang digunakan yaitu metode white box dengan membu

\section{KESIMPULAN}

Berdasarkan hasil pembahasan sebelumnya, maka dapat ditarik kesimpulan sebagai berikut:

Kriteria yang dipakai dalam pemilihan dosen berprestasi yaitu: karya prestasi unggul yang memiliki 3 sub kriteria diantaranya pendidikan dan pembelajaran, penelitian, pengabdian pada masyarakat dan kriteria karya tridarma perguruan tinggi yang memiliki 4 sub kriteria diantaranya pendidikan dan pembelajaran, penelitian, pengabdian pada masyarakat dan keiatan penunjang tridarma.

Hasil perhitungan menggunakan metode MAUTdengan nilai bobot kriteria karya prestasi 
unggul $=60$ dan karya tridarma perguruan tinggi=40. Pada pengujian dengan mengimplementasikan metode MAUT yang menghasilkan nilai tertinggi sampai nilai terendah. Berdasarkan data yang didapat dan dihitung menggunakan metode MAUT maka di rekomendasikan dosen dengan kode dosen D-002 dengan perolehan nilai tertinggi $=300$ dan dosen dengan kode dosen D-001 dengan perolehan nilai terendah $=40$. Dosen dengan perolehan nilai tertinggi yang akan direkomendasikan sebagai dosen berprestasi tingkat Universitas/PTN.

Dosen dengan perolehan nilai tertinggi yang akan direkomendasikan sebagai dosen berprestasi tingkat Universitas/PTN. Hasil pengujian sistem dengan menggunakan metode pengujian system white box telah berhasil dilakukan. Dimana dengan melakukan pengujian pada setiap path-path dalam 13 kali pengujian. Hasil dari implementasi telah sesuai dengan perancangan dan semua modul program telah berfungsi dengan baik. yaitu dirancang dimulai dengan perancangan tampilan / flowchart, desain interfaces, sampai tahap pengkodean dan pengujian. Pengujian menunjukkan bahwa sistem informasi ini berjalan sesuai dengan yang diharapkan, dan tidak terjadi kesalahan logika. Diharapkan agar aplikasi ini dapat dikembangkan sesuai kebutuhan di masa mendatang. android sehingga lebih mempermudah admin/user dalam menggunakan sistem ini.

\section{DAFTAR PUSTAKA}

[1]. T. Mufizar., 2016. "Sistem Pendukung Keputusan Pemilihan Dosen Berprestasi Di STMIK Tasikmalaya Menggunakan Metode Simple Additive Weighting (SAW)". CSRID (Computer Science Research and Its Development Journal), 7(3), 155. https://doi.org/10.22303/csrid.7.3.2015.155166

[2]. R. Gustriansyah., 2016. "Sistem Pendukung Keputusan Pemilihan Dosen Berprestasi". Seminar Nasional Teknologi Informasi Dan Komunikasi, 2016 (Sentika), pp. 18-19.

[3]. A. S. Hanggowibowo., H. Wintolo., Y. Indrianingsih dan R. M Adiba. 2020. "Decision Support System of Lecturer Selection Recommendation with Collaborative Filtering" International Journal on Advanced Science, Engineering and Information Technology. Vol 10. No 2. Pp. 485-490.

[4]. Rasim., E. F. Rahman., N. F. Dewi dan L. S Riza., 2017. "Decision Support Systems for Performance and Evaluation of Teachers in General-English Course by Using the SMARTER and TOPSIS Methods" 1st Annual Applied Science and Engineering Conference. pp. 1-8.

[5]. S. Ningsih., A. Khairan dan F. Tempola., 2019. "Sistem Pendukung Keputusan Pemilihan Tenaga Kesehatan Teladan Pada Dinas Kesehatan Kota Ternate Menggunakan Metode Multy Attribute Utility Theory (Maut)". Patria Artha Technological Journal. Vol. 3 (2), pp.70-82.

[6]. K. A. Umar., S. Lutfi dan F. Tempola. 2019. "Sistem Pendukung Keputusan Rekomendasi Webhosting Pada Kantor Media Online Suaramu. Co Menggunakan Metode Multi Attribute Utility Theory (Maut)". J-TIFA. Vol. 2 (1). pp.34-41.

[7]. E. Turban., J. A. Aronson dan T. P. Liang. 2010. Decision Support System and Intelligent System: ANDI. Yogyakarta

[8]. R. Ramadiani., \& Rahmah, A. 2018. "Sistem Keputusan Pemilihan Tenaga Kesehatan Teladan Menggunakan Metode MultiAttribute Utility Theory". Register: Jurnal Ilmiah Teknologi Sistem Informasi, 5(1), 1. https://doi.org/10.26594/register.v5i1.1273

[9]. G. S. Sasmito. 2017. "Penerapan Metode Waterfall Pada Desain Sistem Informasi Geografis Industri Kabupaten Tegal. Jurnal Informatika: Jurnal Pengembangan IT (JPIT), Vol.2, No.1. pp. 6-12.

[10]. R. Rosihan dan S. Lutfi. 2018. "PENDATAAN KOPERASI PADA DINAS KOPERASI DAN UKM KOTA TERNATE BERBASIS WEB". JIKO (Jurnal Informatika dan Komputer). Vol 1. No 1, pp.13-20. 